\title{
sciendo
}

\section{A practical review of diabetes mellitus type 2 treatment in primary care}

\author{
JUSTIN T. CALL, PEDRO CORTÉS, DANA M. HARRIS
}

Division of Community Internal Medicine, Mayo Clinic, Jacksonville, FL 32224

\author{
Abbreviations: \\ DM2: diabetes mellitus type 2 \\ SGLT-2: sodium-glucose cotransporter 2 \\ GLP-1: glucagon-like peptide 1 \\ ADA: American Diabetes Association \\ HbA1c: Hemoglobin A1C \\ CKD: chronic kidney disease \\ CVD: cardiovascular disease \\ HF: heart failure \\ DKA: diabetic ketoacidosis
}

\begin{abstract}
The treatment of diabetes mellitus type 2 (DM2) is becoming more complex as new medications are approved. Primary care providers must maintain their medical knowledge on emerging medications for best patient care. This review simplifies the non-insulin treatments of diabetes with an emphasis on the cardio-renal protectants, sodium-glucose cotransporter 2 (SGLT2) inhibitors and glucagon-like peptide 1 receptor agonists (GLP-1).
\end{abstract}

Key words: diabetes mellitus type 2, sodium-glucose cotransporter 2, glucagon-like peptide 1 receptor agonists.

\section{What is new? What is important?}

The goal of diabetes care is to improve the quality of life and decrease complications by lowering the mean blood glucose levels. Primary care providers play an essential role in the long-term management of diabetes. By remaining informed of new developments and medications for diabetes, clinicians provide the highest benefits to patients. This comprehensive review shows the evidence behind the effectiveness of diabetes medications on preventing microvascular and macrovascular complications.

\section{INTRODUCTION}

The incidence and prevalence of diabetes mellitus type 2 (DM2) continues to increase worldwide, comprising a global prevalence of $9.3 \%$ [1]. In Romania, the PREDATORR study completed in 2013 found the prevalence of diabetes mellitus to be $11.6 \%$ [2]. Of all the patients diagnosed with diabetes, ninety percent are type 2 . The treatment of DM2 costs 3 times more than average healthcare expenses, and 9 times if treating complications [3]. Similarly, DM2 doubles the risk of cardiovascular and renal disease, and leads to a $25 \%$ reduction in life expectancy $[4,5]$. In the last decade there has been an increase in the number and efficacy of treatments for DM2, providing improved glucose control and cardio-renal protection.

\section{DIAGNOSIS}

The American Diabetes Association (ADA) recommends screening for DM2 in asymptomatic individuals of any age who are overweight (body mass index $[\mathrm{BMI}] 25-29.9 \mathrm{~kg} / \mathrm{m}^{2}$ ) or obese $\left(\right.$ BMI $>30 \mathrm{~kg} / \mathrm{m}^{2}$ ) and have additional risk for diabetes, including first degree relatives with DM2, a history of cardiovascular disease, polycystic ovarian syndrome (PCOS), or acanthosis nigricans, high-risk ethnicities (African American, Latino, Asian American, or Pacific Islander), hypertension (defined as blood pressure $>140 / 90 \mathrm{mmHg}$ ), or low high-density lipoprotein (HDL) level $<35 \mathrm{~mm} / \mathrm{dL}$. The ADA also recommends annual monitoring for individuals with impaired fasting glucose 
(hemoglobin A1C [HbA1c] > 5.7\%), screening women with gestational diabetes every 3 years, and once at age 45 in all other individuals. If normal, screening is repeated every $3-5$ years [6].

\section{MANAGEMENT}

Diabetes mellitus type 2 results from metabolic dysfunction. A sedentary lifestyle, obesity, and advancing age increase the risk of developing DM2, while smoking and alcoholism worsen cardiovascular and renal disease. Therefore, the cornerstone behind DM2 management involves reinforcing a healthy lifestyle, diet and exercise, tobacco cessation and low alcohol intake.

\section{LIFESTYLE MODIFICATIONS}

Lifestyle modifications are as effective as medications for controlling DM2. Maintaining a BMI of $<25 \mathrm{~kg} / \mathrm{m}^{2}$ is recommended. A more intensive weight loss program, and possible bariatric surgery, may be required for obese patients with a BMI > $35 \mathrm{~kg} / \mathrm{m}^{2}$. The 4-year longitudinal Look AHEAD multicenter trial (Action for Health in Diabetes) compared the effects of intensive lifestyle modification to no intervention on glycemic control and cardiovascular disease in diabetic adults [7]. The intensive lifestyle intervention aimed to achieve a $7 \%$ weight loss a year via diet modification and physical activity. Compared to no lifestyle modifications, the intervention group achieved more weight loss, a lower HbA1c and blood pressure, and a higher HDL, with the highest changes occurring in the first year. A mean weight loss of $6 \%$ decreased the $\mathrm{HbA} 1 \mathrm{c}$ by $0.36 \%$ in the intensive lifestyle modification group [7]. Other studies reached similar conclusions. One study showed that a weight loss of $10 \%$ lowered the HbA1c by $0.8 \%$ [8]. Another study found that a weight loss of $7-14 \%$ led to the discontinuation of at least one diabetic medication, and an $11 \%$ reduction in weight resulted in the discontinuation of insulin [9]. Overall, a weight loss of $1 \mathrm{~kg}$ decreases the HbA1c by $0.1 \%$ [10].

Weight loss combined with exercise produces larger results. Exercise and weight loss decrease the risk of progression to DM2 by $40-70 \%$ [8]. Aerobic exercise for at least 150 minutes per week decreases the HbAlc by $0.8 \%$, while also improving strength, physical function, mental health, bone mineral density, blood pressure, lipid profiles, and cardiovascular health [11]. As a comparison, DM2 medications lower the HbA1c by $0.5-1 \%$, up to a maximum of 2 , individually.

\section{MANAGING COMORBIDITIES}

Diabetes increases the risk of myocardial infarction, stroke, liver cirrhosis and end stage renal disease. Cardiovascular complications are the leading cause of morbidity and mortality [3]. Concomitant treatment of hypertension and hyperlipidemia lowers cardiovascular events. The United Kingdom Prospective Diabetes Study (UKPDS) demonstrated that lowering the blood pressure to moderate levels of $144 / 82 \mathrm{mmHg}$ reduced the rate of strokes, diabetes related deaths, heart failure, and microvascular complications [12]. The later trials, ADVANCE and STENO-2, confirmed the findings, showing intensive glucose, blood pressure and lipid interventions reduced cardiovascular mortality. The European Society of Cardiology recommends a systolic blood pressure goal of $120-130 \mathrm{mmHg}$ in patients with DM2.

Lipid lowering recommendations are determined based on an individual's cardiovascular risk. A low-density lipoprotein (LDL) level of less than $2.6 \mathrm{mmol} / \mathrm{L}(<100 \mathrm{mg} / \mathrm{dL})$ is recommended for low-risk patients. Individuals with prior cardiovascular disease are considered high-risk and their LDL levels should be maintained less than $1.8 \mathrm{mmol} / \mathrm{L}(<70 \mathrm{mg} / \mathrm{dL})$ [13].

\section{TREATMENT EVIDENCE}

Treatment of diabetes improves quality of life and decreases complications [3]. Glycemic control decreases microvascular complications such as retinopathy and nephropathy. A decrease of $1 \%$ and $2 \%$ in the $\mathrm{HbA} 1 \mathrm{c}$ decreases retinopathy by $25 \%$ and microvascular complications by $50 \%$, respectively [12]. Intensive primary prevention has greater long-term benefits than improving glycemic control after vascular damages have occurred [14]. While microvascular benefits are clear, it is unclear if glycemic control alone improves macrovascular complications. The Action to Control Cardiovascular Risk in Diabetes (ACCORD) trial highlighted this uncertainty, where intensive treatment of patients with poorly controlled diabetes increased mortality by $22 \%$ [14]. Medications with cardio-renal protection, which decrease the risk of heart failure, hospitalization and progression of renal disease, may alter this finding [15]. 
Until 2008, the approval of diabetes medications depended on glucose control. Since then, newly approved medications must also demonstrate cardiovascular safety after rosiglitazone, a thiazolidinedione (TZD), was found to increase cardiovascular risk. From 2008 until 2015 there was a decline in the use of sulfonylureas (36\% vs 29\%) and thiazolidinediones (21\% vs $9 \%)$, and an increase in the use of dipeptidyl peptidate-4 (DPP-4) $(6.2 \%$ vs $12.4 \%)$, sodium-glucose cotransporter (SGLT-2) $(0.8 \%$ vs 4.4) inhibitors, and glucagon-like peptide-1 (GLP-1) $(2.5 \%$ vs 4.4\%) [16] agonists. This FDA safety measure led to the use of newer classes of medications, such as SGLT-2 inhibitors and GLP-1 agonists, which demonstrated superior safety and cardiorenal protection $[14,17]$.

The Empagliflozin Cardiovascular Outcome Event Trial in Type 2 Diabetes Mellitus Patients (EMPA_REG OUTCOME) was the first trial that showed the superior benefits of SGLT-2 inhibitors on major adverse cardiovascular events (MACE), cardiovascular mortality and heart failure hospitalizations [14]. Since then, five more trials have shown similar results, including the LEADER, SUSTAIN6, CANVAS, REWIND, and DECLARE trials. These trials confirmed the statistically significant reductions in the primary outcome of MACE, including nonfatal myocardial infarction, nonfatal stroke, or death from cardiovascular disease [15]. The American and European guidelines on diabetes now recommend the use of SGLT-2 inhibitors or GLP-1 agonist in individuals who have known atherosclerotic disease or are at high risk for cardiovascular disease regardless of glycemic goal [15].

\section{TREATMENT RECOMMENDATIONS}

The ADA and the European Association for the Study of Diabetes (EASD) recommend a $\mathrm{HbA} 1 \mathrm{c}$ target of less than $53 \mathrm{mmol} / \mathrm{mol}(<7 \%)$ for non-pregnant patients, $64 \mathrm{mmol} / \mathrm{mol}(<8 \%)$ for individuals with a limited life expectancy or if harm exceeds benefit, and $42 \mathrm{mmol} / \mathrm{mol}$ $(<6 \%)$ for pregnant patients. The National Institute of Health and Clinical Excellence (NICE) of the United Kingdom (U.K.) recommends targets of $48 \mathrm{mmol} / \mathrm{mol}(6.5 \%)$ for patients not on medications associated with hypoglycemia, and $53 \mathrm{mmol} / \mathrm{mol}(7.0 \%)$ if a medication associated with hypoglycemia is prescribed [18]. Glucose monitoring with $\mathrm{HbA} 1 \mathrm{c}$ is recommended every 3 months in patients on recently changed therapies and/or who are not meeting their glycemic goal, and at least twice a year thereafter [6].

Oral medications effectively lower the $\mathrm{HbA} 1 \mathrm{C}$ unless it is $\geq 9 \%$ and the patient is symptomatic, in which case insulin is more effective. Metformin is recommended as first line therapy in European and American guidelines. If glycemic control is not achieved, additional medications are added based on comorbidities, cost, and compliance. For patients with cardiovascular and/or renal disease, add an SGLT-2 inhibitor or GLP-1 agonist. An SGLT-2 inhibitor lowers the morning glucose more efficiently than GLP-1 agonists, which have larger effects on the postprandial glucose. If cost is prohibitive, add either a sulfonylurea or a TZD.

\section{OVERVIEW OF GLUCOSE LOWERING MEDICATIONS}

\section{Metformin}

Metformin appeared on the market in the U.S. in 1995 and has since become the first-line therapy for DM2 and has been recommended for primary prevention in obese individuals (BMI > $35 \mathrm{~kg} / \mathrm{m}^{2}$ ) [6]. Its effectiveness and low cost explain metformin's success.

It acts in catabolic pathways to generate adenosine triphosphate (ATP), lower hepatic gluconeogenesis, increase intestinal anaerobic glucose breakdown, reduce adipose-related inflammation, and increase peripheral insulin sensitivity $[19,20]$. Metformin alone lowers the $\mathrm{HbA} 1 \mathrm{c}$ by $0.6 \%$ to $2.0 \%$ in 12 weeks [21]. It is considered weight neutral and does not cause hypoglycemia [20].

Its primary side effect is gastrointestinal upset and diarrhea due to its effect on the intestinal enterocytes and gut-microbiome. Extended-release tablets are better tolerated. [19] Metformin is mainly renally cleared, which increases the risk of lactic acidosis in individuals with decreased renal clearance exacerbated by an infection and/or volume depletion. To reduce this risk, metformin is not recommended for patients with a glomerular filtration rate (GFR) $<30 \mathrm{~mL} /$ $\min / 1.73 \mathrm{~m}^{2}$ [22]. 


Step 1:
$\begin{gathered}\text { Confirm Diagnosis of Type } 2 \text { Diabetes } \\ \text { HbA1e } \geq 6.5 \% \text { or }\end{gathered}$
Fasting blood glucose $>126 \mathrm{mg} / \mathrm{dl}$ or
Random blood glucose $>200 \mathrm{mg} / \mathrm{dl}$ and
symptoms of hyperglycemia

Step 3
Manage Comorbidities
Blood pressure: goal systolic $120-130$
Low CVD risk: LDL-C target of $<2.6 \mathrm{mmol} / \mathrm{L}$
$(<100 \mathrm{mg} / \mathrm{dL})$
High CVD risk: $\mathrm{LDL}-\mathrm{C} \mathrm{of}<1.8 \mathrm{mmol} / \mathrm{L} \quad(<70$
$\mathrm{mg} / \mathrm{dL})$

\section{Step 4}

Consider Metformin Monotherapy

Start dose $500 \mathrm{mg}$ dose after breakfast Can increase by one $500 \mathrm{mg}$ tablet every 1 to 2 weeks as tolerated to a maximum dose $1 \mathrm{gram}$ twice daily after meals

Can consider extended release formulations for $\mathrm{GI}$ intolerance

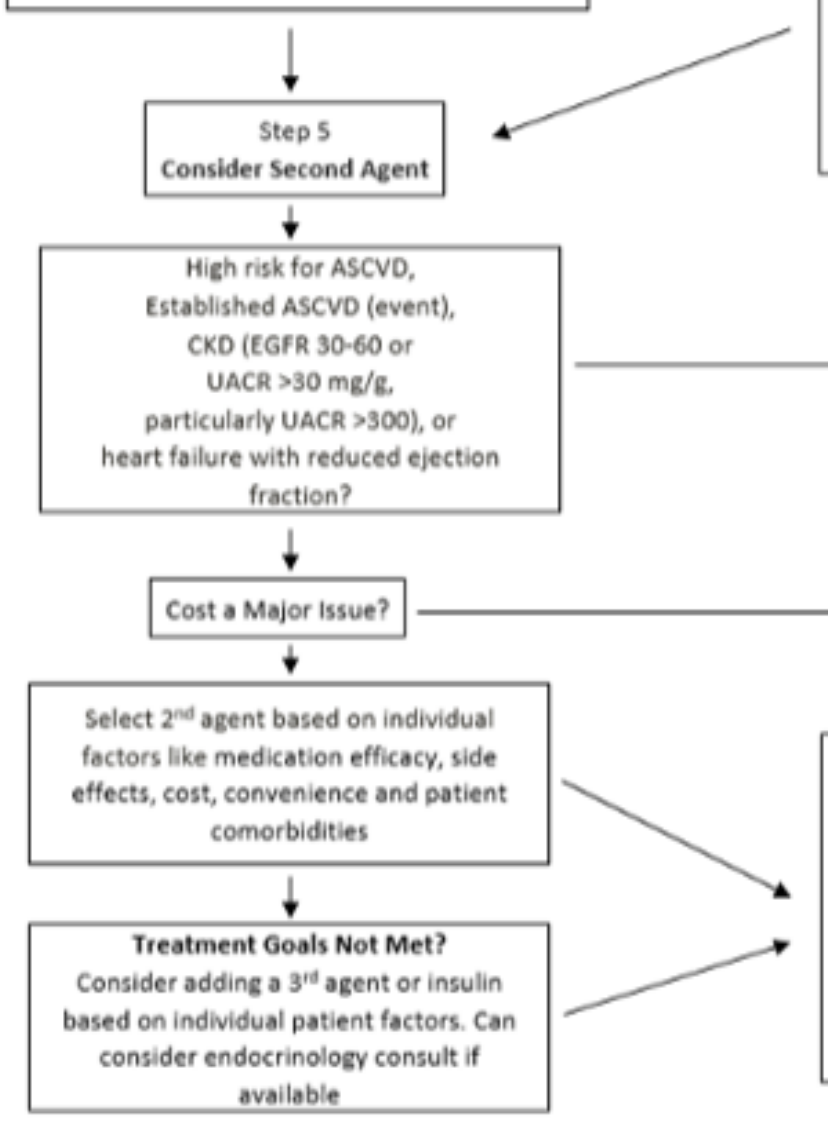

\section{Step 2}

Lifestyle and dietary modifications Improve diet: fewer calories, refined carbohydrates, saturated fats and more fiber.

Weight: Goal weight loss of 5 to $10 \%$ in 1 year. Maintain $B M I<25$.

Physical activity: at least $150 \mathrm{~min} /$ week Smoking cessation

Minimize alcohol intake

If potential for significant improvement in lifestyle, follow up in 3 months with repeat fasting plasma glucose and $\mathrm{HbA1C}$ without

medications
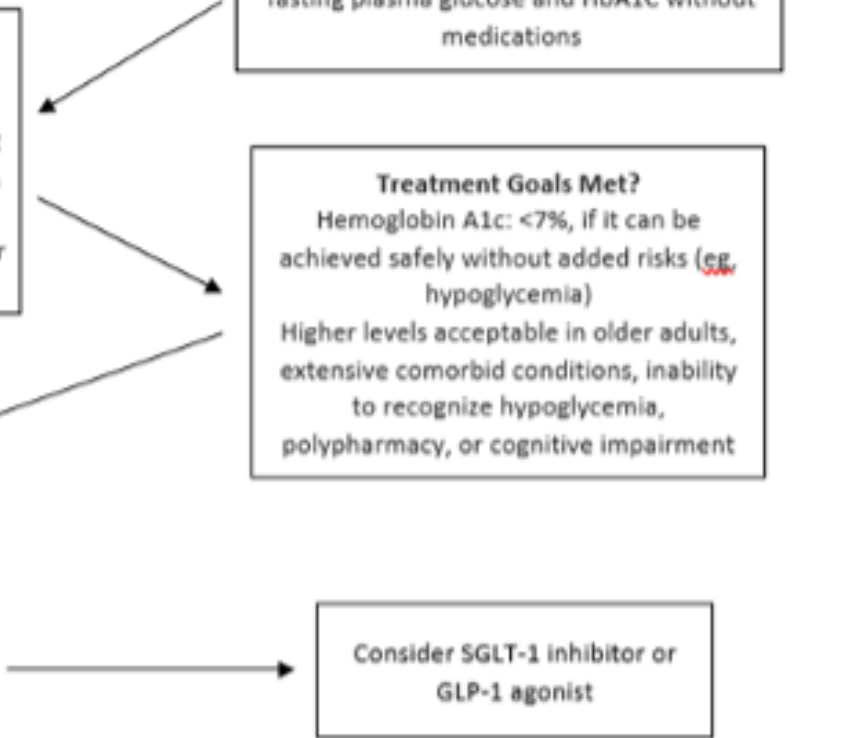

Consider

Sulfonylurea or Thiazolidinedione

Figure 1. Simplified type 2 diabetes non-insulin treatment algorithm* Guidelines.

*Adapted from the 2020 American Diabetes Association (ADA) and European Association for the Study of Diabetes (EASD)

Abbreviations: HbA1C hemoglobin A1C, CVD cardiovascular disease, BMI body mass index, LDL-C low-density lipoprotein cholesterol, GI gastrointestinal, ASCVD atherosclerotic cardiovascular disease, CKD chronic kidney disease, UACR urinary albumin/creatinine ratio, SGLT-1 sodium glucose cotransporter 2, GLP-1 glucagon-like peptide-1. 


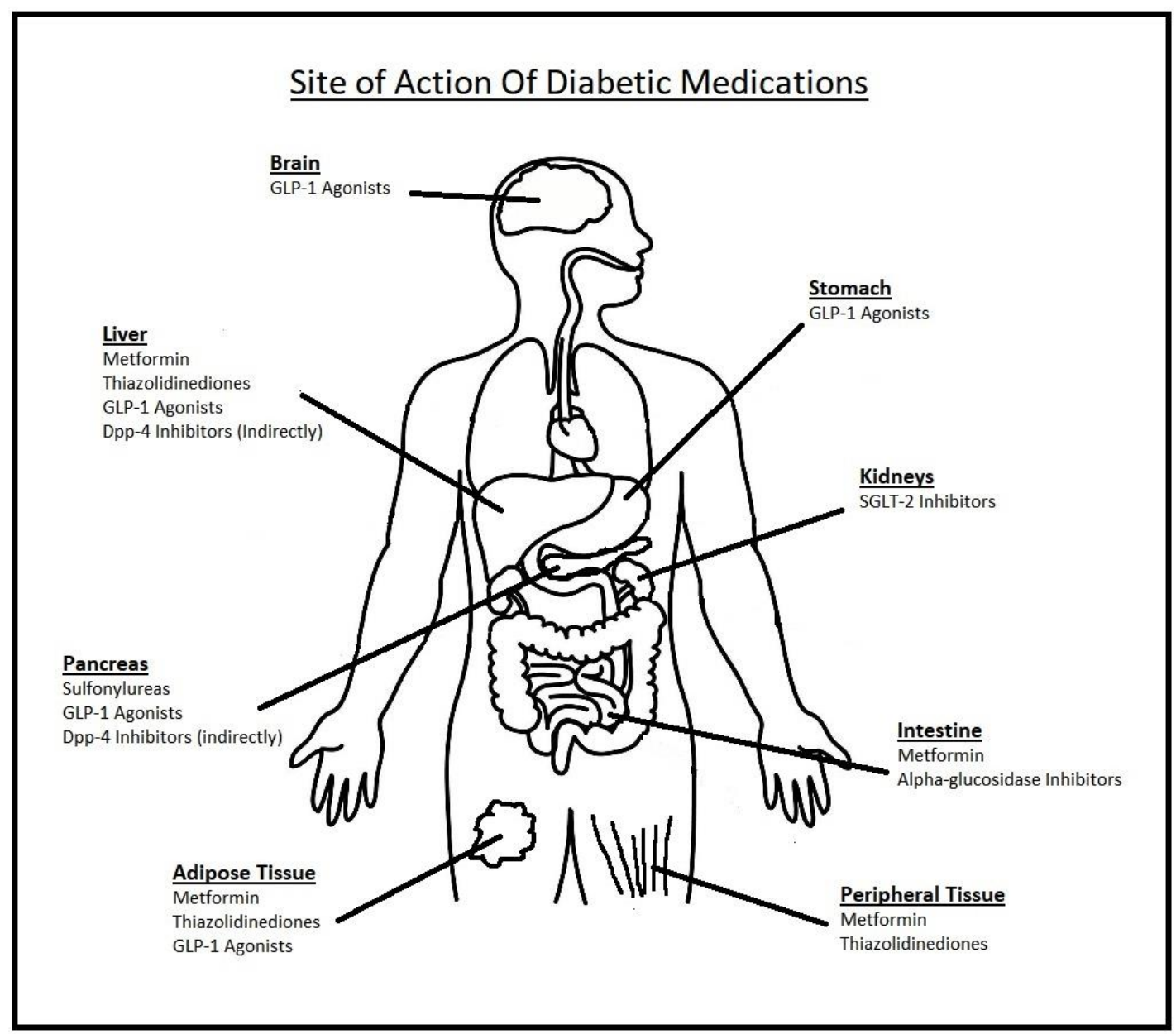

Figure 2. Site of action of diabetic medications

\section{SGLT-2 inhibitors}

The SGLT-2 inhibitors include canagliflozin, dapagliflozin, and empagliflozin. SGLT2 are glucose transporters in the proximal renal tubules and reabsorb $90 \%$ of the glucose filtered [23]. The threshold of glucose reabsorption is 180 $\mathrm{mg} / \mathrm{dL}$ and as high as 220 to $240 \mathrm{mg} / \mathrm{dL}$ in diabetic patients. The inhibition of SGLT-2 prevents this maladaptive response and lowers the reabsorption threshold to 40 to $120 \mathrm{mg} / \mathrm{dL}$ [24].

An SGLT-2 inhibitor lowers the HbA1c by about $0.7 \%$ when compared to placebo [25]. When combined with metformin, empagliflozin at $10 \mathrm{mg}$ and $25 \mathrm{mg}$ improved the HbA1c by $0.57 \%$ and $0.64 \%$ at 24 weeks, respectively [24]. Additionally, SGLT-2 inhibitors significantly lower blood pressure and contribute to weight loss [23]. Across multiple studies, SGLT-2 inhibitors have been found to reduce cardiovascular mortality rate. Similarly, SGLT-2 inhibitors have been shown to slow the progression of renal disease by decreasing weight, blood pressure and albuminuria, and causing long-term stability of GFR [27].

When considering side effects, SGLT-2 inhibitors have an increased risk of minor urinary infections and mycotic genital infections [23]. There have also been the reported risks of dehydration and volume depletion [23]. The early CANVAS trial comparing canagliflozin to placebo found an increased risk of bone fractures, which was not significant in later trials. More recently, rare occurrences of euglycemic diabetic ketoacidosis and Fournier's gangrene have been reported [28].

\section{GLP-1 agonists}

The GLP-1 agonists include semaglutide, albiglutide, dulaglutide, exenatide, liraglutide, and lixisenatide. Glucagon-like peptide is an incretin 
hormone released by intestinal mucosal cells in response to food stimuli, which acts on multiple organ systems. Administration of a GLP-1 agonist increases postprandial insulin release, decreases glucagon levels and free fatty acids, slows gastric emptying, and increases satiety [29]. As a group, GLP-1 agonists reduce HbA1c levels by an average of $0.55 \%$ and fasting blood glucose levels by $0.73 \mathrm{mmol} / \mathrm{L}$ [30]. Additionally, these studies have shown an average weight loss of $1-3 \mathrm{~kg}$ at 12 weeks. More recently, GLP-1 agonists have been found to reduce cardiovascular-related deaths, hospitalization rates for heart failure, and progression of kidney disease [31]. Semaglutide has been shown to reduce the rate of cardiovascular death, nonfatal myocardial infarction or nonfatal stroke in patients with diabetes at high cardiovascular risk [32]. It was also effective at weight loss in obese patients without diabetes, resulting in a mean weight loss of $15 \mathrm{~kg}$. Seventy percent of patients achieved a weight loss of at least 15\%; $50 \%$ achieved a $15 \%$ change, and a third lost $20 \%$. These results in weight reduction are similar to those after a sleeve gastrectomy [33]. The SELECT trial (NCT03574597) will compare semaglutide to placebo regarding MACE in overweight and obese patients with prior cardiovascular disease

The most common side effects of GLP-1 agonists are gastrointestinal, such as nausea, vomiting, and diarrhea, with few reports of acute kidney injury from dehydration [34]. The injectable forms also have a risk of site reactions. Initial concern arose regarding their association with pancreatitis or pancreatic cancer, but later reviews revealed no association $[35,36]$. Preliminary studies have shown a link between GLP-1 agonists and C-cell thyroid tumors in mice, but there have been no associations found in humans [37].

\section{Sulfonylureas}

Sulfonylureas include glipizide, glyburide, glimepiride, tolbutamide, and chlorpropamide. They stimulate the endogenous release of insulin from pancreatic beta-cells and increase the sensitivity to exogenous insulin [38]. Sulfonylureas lower the HbA1c approximately by $1.0 \%$ [38]. Additionally, sulfonylureas have been shown to reduce the insulin requirement to achieve glycemic control. Glimepiride has been shown to reduce the daily insulin requirement on average by 39.2 units at 24 weeks in patients with poorly controlled diabetes [39].
Many clinicians recommend against the use of sulfonylureas alone or for long periods due to the risk of hypoglycemia [40]. As such, patients should be taught the signs of hypoglycemia prior to prescribing. Studies have shown the hypoglycemic effects to be more profound in the elderly.

Most sulfonylureas are renally cleared and should be avoided in renal disease or states that reduce renal clearance. Newer medications, such as gliclazide and gliquidone, are predominantly cleared by the biliary system, and are speculated to be safe in patients with advanced kidney disease [41]. Moreover, sulfonylureas promote weight gain and increase cardiac contractility, and have been shown to increase cardiovascular-related mortality after a myocardial infarction [42].

\section{Thiazolidinediones}

Thiazolidinediones (TZDs) include pioglitazone and rosiglitazone. They activate the transcription factor, peroxisome proliferatoractivated receptor (PPAR gamma), leading to transcription of genes regulating glucose metabolism and fatty acid processing [43]. PPAR gamma is predominantly expressed in adipocyte tissue and has been found to increase insulin sensitization of adipose tissue, muscle, and liver. Current investigations are evaluating if TZDs cause these widespread effects by altering adipocyte hormonal signaling through decreasing free fatty acids and tumor-necrosis alpha [44].

Initial randomized controlled trials estimated that TZDs lowered the HbA1c at 1 year by about $1.0 \%$. Multiple studies, including the DREAM, ADOPT, and CHICAGO trials, have demonstrated that TZDs have similar short-term effects on $\mathrm{HbA1c}$ levels as metformin and sulfonylurea combinations, but have superior long-term effects on the progression of prediabetes [45]. The TZDS have also been shown to lower blood pressure and blood fatty acid levels [46].

Although effective and less expensive, other medications are preferred over TZDs due to their side effects related to fluid retention and weight gain. Other common side effects of TZDs include peripheral edema, macular degeneration, and heart failure [47]. As such, the Federal Drug Association (FDA) of the United States has recommended against using TZDs in patients with heart failure. Generally, TZDs are not recommended in renal impairment due to fluid retention. 


\section{Dipeptidyl peptidase 4 (DPP-4) inhibitors}

The DPP-4 inhibitors include sitagliption, vildaglipton, aloglipton, and saxaglipton. They block the endothelin enzyme, dipeptidyl peptidase, in the degradation of the incretins, GLP-1 and glucose-dependent insulinotropic peptide (GIP). Inhibition of DPP-4 causes a postprandial increase in the incretin hormone levels by up to 3 -fold leading to increased insulin secretion and glucagon suppression [48]. The DPP-4 inhibitors have been found to lower the $\mathrm{HbA} 1 \mathrm{c}$ by $0.28 \%$ to $0.48 \%$ and lead to a lower fasting glucose when compared to metformin and sulfonylureas [49].

The DPP-4 inhibitors are well tolerated with few side effects and are weight neutral [47]. However, a recent meta-analysis revealed a slight increase in the risk of acute pancreatitis [50]. Other trials studying cardiovascular outcomes noted an increase in the rate of heart failure hospitalizations in those with diabetes and heart failure only with saxagliptin $[50,51]$. It was also noted DPP-4 inhibitors may cause severe joint pain that resolves on discontinuation and relapses with restarting of the medication [52].

\section{Alpha-glucosidase inhibitors (acarbose, miglitol, voglibose)}

Alpha-glucosidase inhibitors include acarbose, miglitol and voglibose. They act on the intestinal brush border enzymes, alphaglucosidase, to prevent the breakdown of complex polysaccharides into monosaccharides, decreasing their absorption. Alpha glucosidase inhibitors decrease the HbAlc by $1.0 \%$ compared with placebo [53]. They are weight neutral and not associated with hypoglycemia. They are well tolerated, but high rates of non-adherence have been reported due to flatulence and diarrhea. Patients may also find them difficult to take as they are taken thrice daily before meals. The use of alpha-glucosidase inhibitors has decreased with the development of sulfonylureas and newer novel therapies [54].

\section{Conclusion}

Primary care providers are essential in the long-term management of patients with diabetes. We believe this comprehensive review will facilitate the understanding of the evidence behind older and emerging medications for diabetes.

Tratamentul diabetului zaharat tip 2 (DM2) devine din ce în ce mai complex, intrucât sunt disponibile din ce în ce mai multe clase terapeutice. Medicii din medicina primară trebuie să fie la curent pentru un mai bun management al acestor pacienți. Acest articol trece în revistă și simplifică tratamentele non-insulinice punând accent pe medicația protectoare cardio-renală, SGLT-2 și GLP-1.

Correspondence to: Dana Harris, MD, Mayo Clinic Jacksonville, FL 32224.

Email: Harris.Dana@mayo.edu

Tel: +1 904-953-9543

FAX: + 1 904-953-0655

Conflict of interest disclosure: The authors declare no conflicts of interest. 
Table 1

Summary table of non-insulin diabetes medications

\begin{tabular}{|c|c|c|c|c|c|c|c|}
\hline 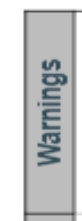 & 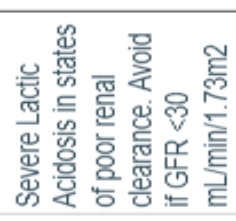 & 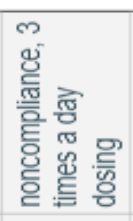 & 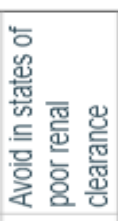 & 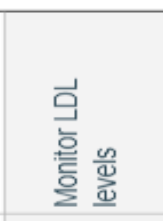 & 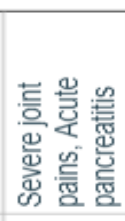 & 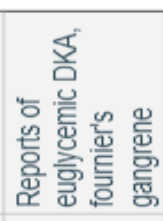 & 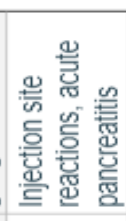 \\
\hline 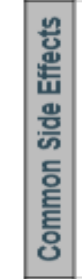 & 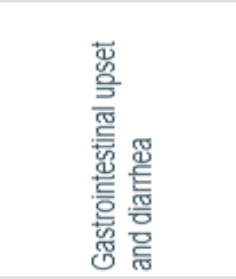 & 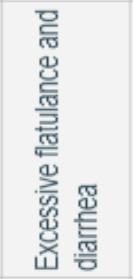 & 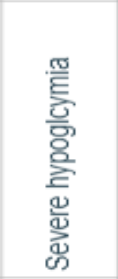 & 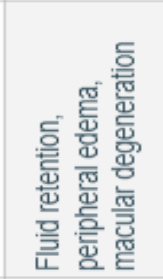 & 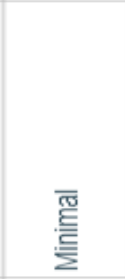 & 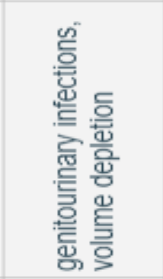 & 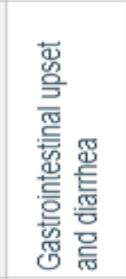 \\
\hline 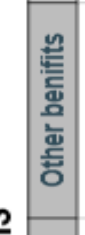 & 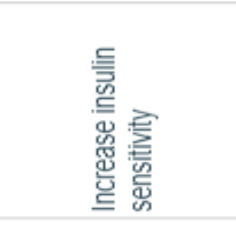 & 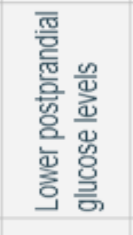 & 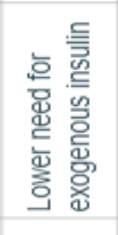 & 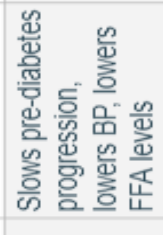 & 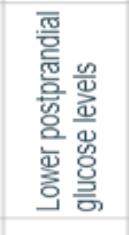 & 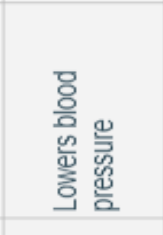 & 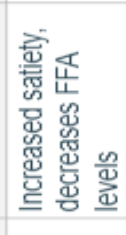 \\
\hline 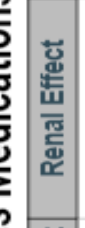 & $\begin{array}{l}\text { 필 } \\
\text { 产 }\end{array}$ & $\begin{array}{l}\text { 필 } \\
\text { 产 }\end{array}$ & $\begin{array}{l}\text { 필 } \\
\text { 产 }\end{array}$ & $\begin{array}{l}\text { 필 } \\
\text { 产 }\end{array}$ & $\begin{array}{l}\text { 필 } \\
\text { 产 }\end{array}$ & 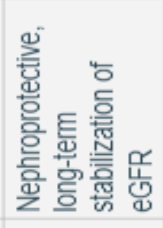 & 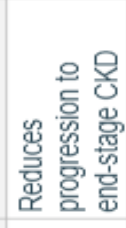 \\
\hline 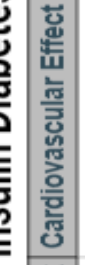 & $\begin{array}{l}\text { 필 } \\
\text { 产 }\end{array}$ & $\begin{array}{l}\text { 필 } \\
\text { 产 }\end{array}$ & 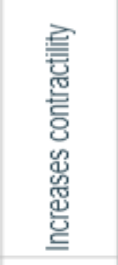 & 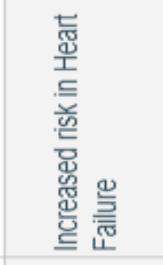 & 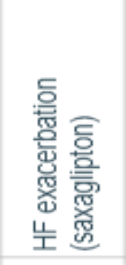 & 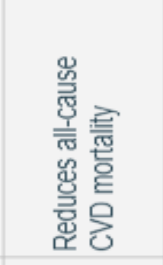 & 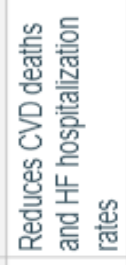 \\
\hline 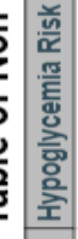 & z & 은 & 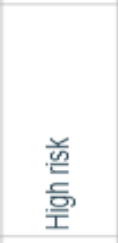 & $\stackrel{\circ}{z}$ & $\stackrel{0}{z}$ & $\stackrel{0}{z}$ & 을 \\
\hline 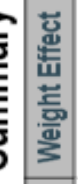 & $\begin{array}{l}\text { 필 } \\
\text { 产 }\end{array}$ & $\begin{array}{l}\text { 필 } \\
\text { 产 }\end{array}$ & 号 & 号 & $\begin{array}{l}\text { 필 } \\
\text { 言 }\end{array}$ & 骂 & 号 \\
\hline 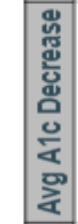 & $\begin{array}{l}\stackrel{0}{0} \\
\stackrel{2}{0} \\
\dot{0} \\
0 \\
i\end{array}$ & ㅇํㅇ & $\begin{array}{l}\stackrel{\circ}{\circ} \\
\stackrel{1}{2}\end{array}$ & $\begin{array}{l}\stackrel{\circ}{\circ} \\
\stackrel{\circ}{2}\end{array}$ & $\begin{array}{l}\text { ¿े } \\
\text { in } \\
\text { in }\end{array}$ & $\frac{\circ}{\hat{i}}$ & $\begin{array}{l}\text { 웅 } \\
\text { in }\end{array}$ \\
\hline 产 & 핑 & 핑 & 중 & 종 & 징 & $\overline{\widetilde{5}}$ & 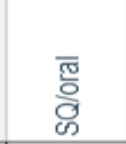 \\
\hline & $\begin{array}{l}\text { c듵 } \\
\text { 高 } \\
\text { 岕 }\end{array}$ & 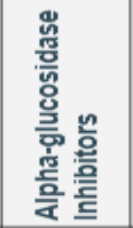 & 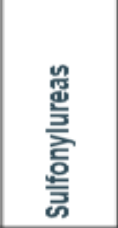 & 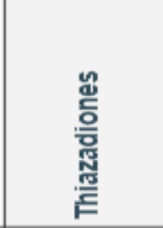 & 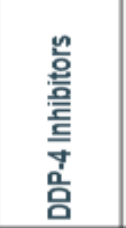 & 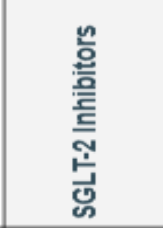 & 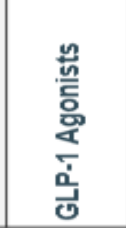 \\
\hline
\end{tabular}




\section{REFERENCES}

1. SAEEDI P., PETERSOHN I., SALPEA P., MALANDA B., KARURANGA S., UNWIN N., et al. IDF Diabetes Atlas Committee. Global and regional diabetes prevalence estimates for 2019 and projections for 2030 and 2045: Results from the International Diabetes Federation Diabetes Atlas, $9^{\text {th }}$ edition. Diabetes Res Clin Pract. 2019;157:107843.

2. MOTA M., POPA SG., MOTA E., MITREA A., CATRINOIU D., CHETA DM., et al. Prevalence of diabetes mellitus and prediabetes in the adult Romanian population: PREDATORR study. J Diabetes. 2016;8(3):336-44.

3. TSOUTSOUKI J., WUNNA W., CHOWDHURY A., CHOWDHURY TA. Advances in the management of diabetes: therapies for type 2 diabetes. Postgrad Med J. 2020;96(1140):610-618.

4. SHIN JL. Second-line Glucose-Lowering Therapy in Type 2 Diabetes Mellitus. Curr Diab Rep. 2019;19(8):54.

5. CHARBONNEL B., DORMANDY K., ERDMANN E., MASSI-BENEDETTI M., SKENE A. PROactive Study Group. The prospective pioglitazone clinical trial in macrovascular events (PROactive): can pioglitazone reduce cardiovascular events in diabetes? Study design and baseline characteristics of 5238 patients. Diabetes Care. 2004;27(7):1647-53.

6. AMERICAN DIABETES ASSOCIATION. Standards of Medical Care in Diabetes-2021 Abridged for Primary Care Providers. Clin Diabetes. 2021;39(1):14-43.

7. LOOK AHEAD RESEARCH GROUP., WING RR. Long-term effects of a lifestyle intervention on weight and cardiovascular risk factors in individuals with type 2 diabetes mellitus: four-year results of the Look AHEAD trial. Arch Intern Med. 2010;170(17):1566-75.

8. SHANTHA GP., KUMAR AA., KAHAN S., CHESKIN LJ. Association between glycosylated hemoglobin and intentional weight loss in overweight and obese patients with type 2 diabetes mellitus: a retrospective cohort study. Diabetes Educ. 2012;38(3):417-26.

9. KUMAR AA., PALAMANER SUBASH SHANTHA G., KAHAN S., SAMSON RJ., BODDU ND., CHESKIN LJ. Intentional weight loss and dose reductions of anti-diabetic medications--a retrospective cohort study. PLoS One. 2012;7(2):e32395.

10. GUMMESSON A., NYMAN E., KNUTSSON M., KARPEFORS M. Effect of weight reduction on glycated haemoglobin in weight loss trials in patients with type 2 diabetes. Diabetes Obes Metab. 2017;19(9):1295-1305.

11. COLBERG SR., SIGAL RJ., YARDLEY JE., RIDDELL MC., DUNSTAN DW., DEMPSEY PC., et al. Physical Activity/Exercise and Diabetes: A Position Statement of the American Diabetes Association. Diabetes Care. 2016;39(11):2065-2079.

12. HELLER SR. ADVANCE Collaborative Group. A summary of the ADVANCE Trial. Diabetes Care. 2009;32 Suppl 2 (Suppl 2): S357-61.

13. COSENTINO F., GRANT PJ., ABOYANS V., BAILEY CJ., CERIELlO A., DELGADO V., et al. ESC Scientific Document Group. 2019 ESC Guidelines on diabetes, pre-diabetes, and cardiovascular diseases developed in collaboration with the EASD. Eur Heart J. 2020;41(2):255-323.

14. BAILEY CJ., MARX N. Cardiovascular protection in type 2 diabetes: Insights from recent outcome trials. Diabetes Obes Metab. 2019;21(1):3-14.

15. KALYANI RR. Glucose-Lowering Drugs to Reduce Cardiovascular Risk in Type 2 Diabetes. N Engl J Med. 2021;384(13):1248-1260.

16. RAVAL AD., VYAS A. National Trends in Diabetes Medication Use in the United States: 2008 to 2015. J Pharm Pract. 2020;33(4):433-442.

17. LIBIANTO R., DAVIS TM., EKINCI EI. Advances in type 2 diabetes therapy: a focus on cardiovascular and renal outcomes. Med J Aust. 2020;212(3):133-139.

18. NATIONAL INSTITUTE FOR HEALTH AND CARE EXCELLENCE (UK). Type 2 diabetes in adults: management. London: National Institute for Health and Care Excellence (UK); 2015.

19. RENA G., HARDIE DG., PEARSON ER. The mechanisms of action of metformin. Diabetologia. 2017;60(9):1577-1585.

20. FORETZ M., GUIGAS B., VIOLLET B. Understanding the glucoregulatory mechanisms of metformin in type 2 diabetes mellitus. Nat Rev Endocrinol. 2019;15(10):569-589.

21. GARBER AJ., DUNCAN TG., GOODMAN AM., MILLS DJ., ROHLF JL. Efficacy of metformin in type II diabetes: results of a double-blind, placebo-controlled, dose-response trial. Am J Med. 1997;103(6):491-497.

22. MARIANO F., BIANCONE L. Metformin, chronic nephropathy and lactic acidosis: a multi-faceted issue for the nephrologist J Nephrol. 2020. Epub ahead of print.

23. SCHEEN AJ. Pharmacodynamics, efficacy and safety of sodium-glucose co-transporter type 2 (SGLT2) inhibitors for the treatment of type 2 diabetes mellitus. Drugs. 2015;75(1):33-59.

24. DESOUZA CV., GUPTA N., PATEL A. Cardiometabolic Effects of a New Class of Antidiabetic Agents. Clin Ther. 2015;37(6):1178-1194.

25. VASILAKOU D., KARAGIANNIS T., ATHANASIADOU E., MAINOU M., LIAKOS A., BEKIARI E., et al. Sodium-glucose cotransporter 2 inhibitors for type 2 diabetes: a systematic review and meta-analysis. Ann Intern Med. 2013;159(4):262-74.

26. LIBIANTO R., DAVIS TM., EKINCI EI. Advances in type 2 diabetes therapy: a focus on cardiovascular and renal outcomes. Med J Aust. 2020;212(3):133-139.

27. RABIZADEH S., NAKHJAVANI M., ESTEGHAMATI A. Cardiovascular and Renal Benefits of SGLT2 Inhibitors: A Narrative Review. Int J Endocrinol Metab. 2019;17(2):e84353.

28. CHEEN AJ. An update on the safety of SGLT2 inhibitors. Expert Opin Drug Saf. 2019;18(4):295-311.

29. HINNEN D. Glucagon-Like Peptide 1 Receptor Agonists for Type 2 Diabetes. Diabetes Spectr. 2017;30(3):202-210.

30. HTIKE ZZ., ZACCARDI F., PAPAMARGARITIS D., WEBB DR., KHUNTI K., DAVIES MJ. Efficacy and safety of glucagon-like peptide-1 receptor agonists in type 2 diabetes: A systematic review and mixed-treatment comparison analysis. Diabetes Obes Metab. 2017;19(4):524-536. 
31. KRISTENSEN SL., RØRTH R., JHUND PS., DOCHERTY KF., SATTAR N., PREISS D., et al. Cardiovascular, mortality, and kidney outcomes with GLP-1 receptor agonists in patients with type 2 diabetes: a systematic review and meta-analysis of cardiovascular outcome trials. Lancet Diabetes Endocrinol. 2019;7(10):776-785.

32. MARSO SP., BAIN SC., CONSOLI A., ELIASCHEWITZ FG., JÓDAR E., LEITER LA., et al. Semaglutide and Cardiovascular Outcomes in Patients with Type 2 Diabetes. N Engl J Med. 2016;375(19):1834-1844.

33. WILDING JPH., BATTERHAM RL., CALANNA S., DAVIES M., VAN GAAL LF., LINGVAY I., et al. Once-Weekly Semaglutide in Adults with Overweight or Obesity. N Engl J Med. 2021;384(11):989.

34. FILIPPATOS TD., PANAGIOTOPOULOU TV., ELISAF MS. Adverse Effects of GLP-1 Receptor Agonists. Rev Diabet Stud. 2014;11(3-4):202-230.

35. STOGAARD H., COLD F., GLUUD LL., VILSBØLL T., KNOP FK. Glucagon-like peptide-1 receptor agonists and risk of acute pancreatitis in patients with type 2 diabetes. Diabetes Obes Metab. 2017;19(6):906-908.

36. PINTO LC., FALCETTA MR., RADOS DV., LEITÃO CB. GROSS JL. Glucagon-like peptide-1 receptor agonists and pancreatic cancer: a meta-analysis with trial sequential analysis. Sci Rep. 2019;9(1):2375.

37. CAO C., YANG S., ZHOU Z. GLP-1 receptor agonists and risk of cancer in type 2 diabetes: an updated meta-analysis of randomized controlled trials. Endocrine. 2019;66(2):157-165.

38. LEROITH D., BIESSELS GJ., BRAITHWAITE SS., CASANUEVA FF., DRAZNIN B., HALTER JB., et al. Treatment of Diabetes in Older Adults: An Endocrine Society* Clinical Practice Guideline. J Clin Endocrinol Metab. 2019;104(5):1520-1574.

39. LI CJ., ZHANG JY., YU DM., ZHANG QM. Adding glimepiride to current insulin therapy increases high-molecular weight adiponectin levels to improve glycemic control in poorly controlled type 2 diabetes. Diabetol Metab Syndr. 2014 Mar 20;6(1):41.

40. KABADI M., KABADI U. Efficacy of Sulfonylureas with Insulin in Type 2 Diabetes Mellitus. Ann Pharmacother. 2003;37(11):1572-6.

41. SOLA D., ROSSI L., SCHIANCA GP., MAFFIOLI P., BIGLIOCCA M., MELLA R., et al. Sulfonylureas and their use in clinical practice. Arch Med Sci. 2015;11(4):840-8.

42. RAO AD., KUHADIYA N., REYNOLDS K., FONSECA VA. Is the combination of sulfonylureas and metformin associated with an increased risk of cardiovascular disease or all-cause mortality?: a meta-analysis of observational studies. Diabetes Care. 2008;31(8):1672-1678.

43. HAUNER H. The mode of action of thiazolidinediones. Diabetes Metab Res Rev. 2002;18 Suppl 2:S10-S15.

44. HUSSEIN Z., WENTWORTH JM., NANKERVIS AJ., PROIETTO J., COLMAN PG. Effectiveness and side effects of thiazolidinediones for type 2 diabetes: real-life experience from a tertiary hospital. Med J Aust. 2004;181(10):536-539.

45. GOLDBERG RG. The new clinical trials with thiazolidinediones--DREAM, ADOPT, and CHICAGO: promises fulfilled? Curr Opin Lipidol. 2007;18(4):435-442.

46. DELLA-MORTE D., PALMIROTTA R., REHNI AK., PASTORE D., CAPUANI B., PACIFICI F., et al. Pharmacogenomics and pharmacogenetics of thiazolidinediones: role in diabetes and cardiovascular risk factors. Pharmacogenomics. 2014;15(16):2063-82.

47. RIZOS CV., ELISAF MS., MIKHAILIDIS DP., LIBEROPOULOS EN. How safe is the use of thiazolidinediones in clinical practice? Expert Opin Drug Saf. 2009;8(1):15-32.

48. THORNBERRY NA., GALLWITZ B. Mechanism of action of inhibitors of dipeptidyl-peptidase-4 (DPP-4). Best Pract Res Clin Endocrinol Metab. 2009;23(4):479-486.

49. AHRÉN B. Emerging dipeptidyl peptidase-4 inhibitors for the treatment of diabetes. Expert Opin Emerg Drugs. 2008;13(4):593-607.

50. LAMOS EM., HEDRINGTON M., DAVIS SN. An update on the safety and efficacy of oral antidiabetic drugs: DPP-4 inhibitors and SGLT-2 inhibitors. Expert Opin Drug Saf. 2019;18(8):691-701.

51. SCIRICA BM, BHATT DL., BRAUNWALD E. STEG PG., DAVIDSON J., HIRSHBERG B., et al. Saxagliptin and cardiovascular outcomes in patients with type 2 diabetes mellitus. N Engl J Med. 2013;369(14):1317-26.

52. MEN P., HE N., SONG C., ZHAI S. Dipeptidyl peptidase-4 inhibitors and risk of arthralgia: A systematic review and metaanalysis. Diabetes Metab. 2017;43(6):493-500.

53. HOFFMAN J., SPENGLER M. Efficacy of 24-week monotherapy with acarbose, glibenclamide, or placebo in NIDDM patients. The Essen Study. Diabetes Care. 1994;17(6):561-566.

54. MENEILLY GS., RYAN EA., RADZIUK J., LAU DC., YALE JF., MORAIS J., et al. Effect of acarbose on insulin sensitivity in elderly patients with diabetes. Diabetes Care. 2000;23(8):1162-7.

Received $18^{\text {th }}$ June 2021 